\title{
Komunikasi Politik dan Branding Pemimpin Politik Melalui Media Sosial: A Conceptual Paper
}

\author{
Festy Rahma Hidayati ${ }^{1}$ \\ ${ }^{1}$ Fakultas Ilmu Sosial dan Ilmu Politik, Universitas Indonesia \\ Jl. Margonda Raya, Pondok Cina, Kecamatan Beji, Kota Depok, Jawa Barat \\ E-mail: ${ }^{1}$ festy.rahma@ui.ac.id
}

Received: June 2021; Accepted: October 2021; Published: December 2021

\begin{abstract}
The presence of digital media, such as social media allows us to connect without any limitations of space and time. Consumption of social media brings changes in various aspects of life, including the habits of communicating and interacting in today's network society. In the political field, social media creates opportunities for political leaders to carry out political communication. As a strategic political communication channel, social media plays a role in receiving and responding to public aspirations. In fact, the use of social media for campaigns by political leaders shows a trend of increasing popularity and electability due to the influence of branding on social media. The use of social media by political leaders in building specific branding is at the core of this article. Political leaders optimize their personal social media accounts for political communication. The positive perception of the public allows for an increase in popularity and electability which brings to the national political stage. This article is a conceptual paper that analyzes the concept of branding in politics in the era of digital political communication by utilizing social media. The author uses relevant literature reviews from previous studies. This article reveals that several political leaders that have been studied have optimized social media to carry out political communication to their citizens. They display digital content to gain public support and trust, and display branding as a populist, professional, humanist, and responsible political leader.
\end{abstract}

Keywords: political communication; branding; political leadership; social media

\begin{abstract}
Abstrak
Kehadiran media digital, seperti media sosial memungkinkan kita terhubung tanpa ada batasan ruang dan waktu. Konsumsi media sosial membawa perubahan dalam berbagai aspek kehidupan, termasuk kebiasaan berkomunikasi dan berinteraksi masyarakat jaringan saat ini. Di bidang politik, media sosial menciptakan peluang bagi pemimpin politik untuk melakukan komunikasi politik. Sebagai saluran komunikasi politik yang strategis, media sosial berperan untuk menerima dan merespon aspirasi publik. Bahkan, penggunaan media sosial untuk kampanye oleh pemimpin politik menunjukkan adanya tren peningkatan popularitas dan elektabilitas karena pengaruh branding di media sosial. Penggunaan media sosial oleh pemimpin politik dalam membangun branding tertentu menjadi inti artikel ini. Pemimpin politik mengoptimalkan akun media sosial pribadi mereka untuk melakukan komunikasi politik. Persepsi positif dari publik memungkinkan adanya peningkatan popularitas dan elektabilitas yang membawa ke panggung politik nasional. Artikel ini merupakan conceptual paper yang menganalisis konsep branding dalam politik di era komunikasi politik digital dengan memanfaatkan media sosial. Penulis menggunakan literature review yang relevan dari penelitian sebelumnya. Artikel ini mengungkap bahwa beberapa pemimpin politik yang pernah diteliti telah mengoptimalkan media sosial untuk melakukan komunikasi politik kepada warganya. Mereka menampilkan konten-konten digital untuk mendapatkan dukungan dan kepercayaan masyarakat, serta menampilkan branding sebagai pemimpin politik yang populis, profesional, humanis, dan bertanggung jawab.
\end{abstract}

Kata Kunci: komunikasi politik; branding; pemimpin politik; media sosial

doi: https://doi.org/10.51544/jlmk.v5i2.2385

(C) 2021 Jurnal Lensa Mutiara Komunikasi. This is an open access article under the CC BY-SA license Website: http://e-journal.sari-mutiara.ac.id/index.php/JLMI

http://e-journal.sari-mutiara.ac.id 


\section{PENDAHULUAN}

Keberhasilan teknologi informasi dan komunikasi yang ditandai dengan kehadiran internet membawa perubahan cara berkomunikasi saat ini. Kehadiran media digital, seperti media sosial, memungkinkan adanya keterhubungan di mana tanpa ada batasan ruang dan waktu. Dalam literatur kontemporer ditandai dengan adagium seperti 'connected world', 'connected age', 'human web', dan 'web society' (Dijk, V., 2006).

Saat ini, internet (bersama dengan munculnya media digital) mempengaruhi segalanya mulai dari cara kita berbelanja, membaca berita, dan menjalani kehidupan sehari-hari hingga cara bisnis, parlemen, dan pemerintah, sehingga mengubah tatanan sosial, institusi politik, dan ekonomi. Transformasi digital ini telah menciptakan tantangan dan peluang baru bagi politisi, jurnalis, institusi politik, dan media untuk menghubungkan kembali dan terlibat dengan warganya. Media sosial menghadirkan struktur peluang politik baru (Schwanholz J. \& Graham T, 2018).

Di bidang politik, internet menciptakan partisipasi aktif antar pemerintah dan warga negara. Internet menjadi alternatif saluran komunikasi untuk negara dan masyarakat yang sudah maju dalam aspek sumber daya informasi (Norris, P., 2001). Teknologi internet telah menjadi sumber informasi peradaban saat ini. Dijk.,V. (2006) menjelaskan, teknologi memang memungkinkan distribusi pengetahuan yang lebih baik. Kehadiran internet juga memungkinkan meningkatkan partisipasi masyarakat, memobilisasi jaringan komunitas dan koalisi serta lobi politik.

Perkembangan internet selanjutnya melahirkan media sosial yang pemanfaatannya bagi sebagian masyarakat dunia telah menjadi bagian dari gaya hidup modern. Media sosial mendorong proses interaksi sosial yang bersifat dua arah. Dengan dukungan teknologi internet maka dapat mengubah pola komunikasi dari one to many audience menjadi many to many audience.

Mengutip informasi yang dikeluarkan oleh HootSuite dan We Are Social pada Januari 2021, jumlah pengguna internet di dunia mencapai 4,66 miliar orang. Sebagian besar memanfaatkannya untuk media sosial sebanyak 4,2 miliar orang. Indonesia adalah salah satu negara dengan pengguna internet (termasuk media sosial) terbesar di dunia. Di Indonesia, terdapat 202,6 juta pengguna internet atau 73,7 persen dari seluruh populasi 274,9 juta penduduk secara keseluruhan. Jumlah ini meningkat 27 juta (+16\%) dibandingkan tahun 2020. Dari jumlah tersebut, terdapat 170 juta pengguna media sosial atau $61,8 \%$ dari seluruh penduduk Indonesia. Jumlah pengguna media sosial meningkat 10 juta $(+6,3 \%)$ dibandingkan tahun 2020 (Kemp, 2021).

Jumlah pengguna media sosial yang cukup potensial ini melahirkan peluang untuk memperkuat dan memperkaya hubungan antara warga negara dengan pemimpin pusat, pemimpin daerah, tokoh politik, pejabat publik, partai politik, gerakan sosial dan kelompok kepentingan, media, serta lembaga lokal, nasional, dan pemerintahan global. Media sosial mempengaruhi kehidupan sosial karena mengubah cara berkomunikasi dan berinteraksi satu sama lain. Media sosial, seperti Twitter, Facebook, Instagram, Youtube, Podcast, dan lainnya menjadi saluran komunikasi digital mainstream yang berpengaruh terhadap meningkatnya partisipasi demokrasi.

Media sosial menunjang perkembangan demokrasi dan komunikasi politik di berbagai negara. Salah satu ilustrasinya adalah kebangkitan Dunia Arab atau yang dikenal dengan istilah Arab Spring. Gerakan sosial melalui media sosial ini berhasil menjatuhkan rezim yang berkuasa di beberapa negara Arab seperti Tunisia dan Mesir. Pada perkembangan selanjutnya, berkembang gerakan sosial Occupy Wall Street di New York pada tahun 2011. Gerakan 
sosial ini kemudian menginspirasi negara lainnya di dunia sehingga berhasil membawa perubahan di bidang ekonomi dan sosial (Khamis, Sahar, 2013). Sementara itu, kemenangan Barack Obama pada pemilihan Presiden Amerika Serikat pada 2008 membuktikan bahwa internet memiliki kekuatan untuk mempengaruhi pemilih menjadikan Barack Obama sebagai Presiden Amerika Serikat (Norris, 2011).

Media sosial dianggap memiliki peran strategis sebagai media perubahan dan perkembangan, serta sebagai media yang efektif untuk menerima dan merespon aspirasi publik. Bahkan, media sosial dioptimalkan oleh pemimpin di pemerintahan daerah hingga pusat untuk menjaga komunikasi politik dengan masyarakat, sekaligus membangun personal branding melalui komunikasi politik di media sosial (Hafizatullah, Salamah \& Wangi, 2017; Marland, 2018; Hultman, M., 2019).

Melalui media sosial, para pemimpin politik di tingkat lokal hingga nasional menerima dan merespon aspirasi publik. Berdasarkan literatur terdahulu, pemimpin politik ini mampu menjaga komunikasi dan interaksi dengan warganya. Komunikasi politik di media sosial ini dapat menumbuhkan budaya partisipasi, aspirasi, dan kedekatan tanpa ada batasan ruang dan waktu.

Kebijakan para pemimpin politik juga optimal apabila dikomunikasikan melalui media sosial. Hal itu diyakini akan meningkatkan dukungan politik, kepercayaan terhadap kinerja pemerintah, dan demokrasi. Pemimpin politik mendapatkan dukungan dan kepercayaan masyarakat dengan menampilkan brand sebagai pemimpin populis, bertanggung jawab, dan profesional.

Salah satu cara media sosial meningkatkan partisipasi demokrasi adalah melalui potensi konektivitas global dari teknologi ini. Penggunaan media sosial untuk kampanye oleh pemimpin politik di banyak negara menunjukkan adanya tren peningkatan personalisasi dalam pemilihan pemimpin politik di tingkat lokal hingga nasional. Studi yang dilakukan Darwin\& Haryanto (2021) mengkaji pola personalisasi calon legislatif perempuan menggunakan media sosial di tingkat lokal di Indonesia yang merupakan negara muslim demokratis terbesar di dunia. Studi ini menjelaskan tren personalisasi Islam yang meningkat secara signifikan di media sosial, yang telah mendukung tumbuhnya partisipasi politik perempuan dalam kampanye pemilu, dan keterwakilan mereka di parlemen lokal.

Peran media sosial dan pengaruh citra kandidat di Inggris dalam membangun kesetaraan hubungan pemilih-kandidat juga menjadi temuan dalam studi yang dilakukan Hultman, et. al (2019). Media sosial tampaknya berpengaruh positif terhadap citra kandidat. Dengan mengambil dari literatur branding dan teori identitas sosial, artikel ini menyelidiki lebih lanjut peran citra kandidat sebagai mediator antara media sosial dan kesetaraan hubungan pemilih-kandidat, sementara juga menguji efek moderasi dari ideologi politik. Hasil survei dari 235 pemilih muda Inggris menunjukkan bahwa media sosial tampaknya berpengaruh positif terhadap citra kandidat, tetapi tidak semua variabel media sosial berhubungan langsung dengan ekuitas hubungan.

Media sosial seperti Twitter, Facebook, Instagram dan Youtube memiliki potensi penting dalam menembus dan menghubungkan populasi global. Media sosial memiliki kapasitas laten yang sangat besar untuk menjembatani dan memfasilitasi pertumbuhan modal sosial. Berdasarkan uraian di atas, maka tampak peran media sosial khususnya dalam memberikan alternatif dalam berdemokrasi dalam konsep komunikasi politik digital. Artikel ini akan membahas konsep branding dalam politik di era komunikasi politik digital dengan memanfaatkan media sosial. Penulis menggunakan konsep dan literatur tentang komunikasi politik dan branding dalam politik di era digital. 


\section{TINJAUAN LITERATUR}

\section{Komunikasi Politik di Era Digital}

Komunikasi dalam politik berperan penting dalam mobilisasi politik, membangun kepercayaan baik pada aktor politik maupun pemerintah. Pemimpin politik membangun pesan melalui penciptaan branding yang cermat karena kekuatan simbol dan tanda yang disampaikan berpengaruh kuat. McNair (1995) menjelaskan, komunikasi politik konvesional adalah penyampaian pesan untuk tujuan politis yang ditandai ciri-ciri: aktor politik melakukan penyampaian pesan untuk mencapai tujuan tertentu; penyampaian pesan dari aktor nonpolitik kepada aktor politik, dan penyampaian pesan dari aktor politol melalui media massa.

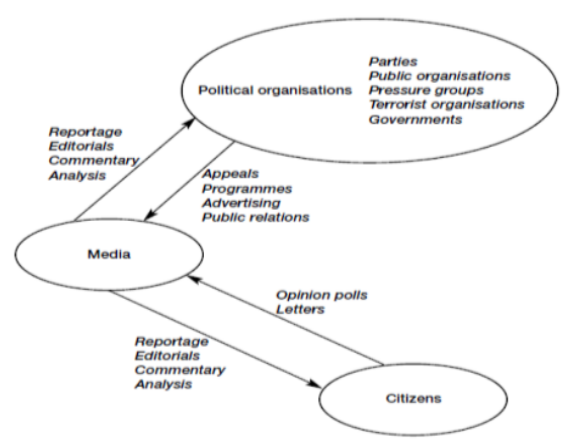

Gambar 1. Komunikasi Politik melalui Media Massa Tradisonal

Kemudian dalam dua dekade terakhir, internet telah mempengaruhi bermacam aspek kehidupan manusia termasuk demokrasi. Di Indonesia, sejak kedatangan internet pada akhir 1990-an, komunikasi politik mulai bergeser dari yang bersifat konvensional ke digital. Dengan karakter yang maka menciptakan peluang dan tantangan bagi para aktor politik berkomunikasi politik yang efektif dan berkualitas dengan khalayak.

Komunikasi politik ini didefinisikan sebagai aktivitas komunikasi yang kompleks dengan menggunakan bahasa dan simbol, yang digunakan oleh para pemimpin, media, warga negara, kelompok warga, ahli untuk memberikan efek dan pada hasil yang dikenakan pada kebijakan publik bangsa, negara, atau masyarakat (Perloff, 2021). Komunikasi politik tradisional dalam bentuk orasi, pidato, ceramah, kini dioptimalkan melalui media sosial seperti Facebook, Twitter, Instagram, dan YouTube dalam bentuk kampanye di dunia maya (cyber-campaign).

Perloff (2021) menjelaskan ada tujuh dimensi utama dari komunikasi politik, yaitu aktivitas komunikasi yang menjembatani antara institusi politik dan media; menekankan pada simbol dan bahasa, mediation and mediatization; teknologi media; diverse, multifaceted media, and decline of gatekeeping; interaksi di antara pemimpin, media, dan warga, serta fungsi struktur ekonomi dan politik. 


\section{Tabel 1 \\ Care of Political Communication}

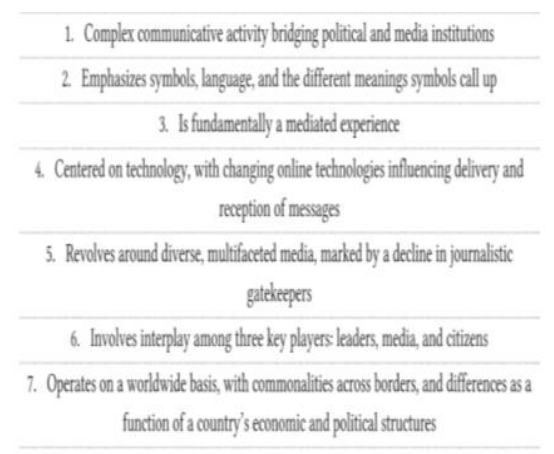

(Sumber: Perloff, 2021)

Media sosial memungkinkan aktor politik mengurangi biaya yang dibutuhkan dalam kampanye politik. Dengan mengoptimalkan akun media sosial pribadi, maka seorang pemimpin politik dapat menjangkau pengikutinya dengan lebih luas. Di Indonesia, contoh pejabat publik dengan jumlah pengikut media sosial terbanyak di tahun 2021 setelah Presiden Joko Widodo adalah Gubernur Jawa Barat Ridwan Kamil, yaitu 13,9 juta di Instagram, 4,4 juta di Twitter dan 3,4 juta di Facebook.

Perusahaan teknologi, khususnya Facebook, Twitter, Microsoft, dan Google, berperan dalam membentuk komunikasi politik kampanye pemilu di Amerika Serikat (Daniel Kreiss \& Shannon C. McGregor, 2018). Perusahaan teknologi tersebut termotivasi untuk bekerja di ruang politik untuk pemasaran, pendapatan iklan, dan pembangunan hubungan dalam layanan upaya lobi. Untuk memfasilitasi ini, perusahaan-perusahaan ini telah mengembangkan struktur organisasi dan pola kepegawaian yang sesuai dengan sifat partisan politik Amerika. Selain itu, Facebook, Twitter, dan Google lebih dari sekadar mempromosikan fitur-fitur tersedia dan iklan digital. Perusahaan digital tersebut juga menyediakan kampanye politik bagi politis. Mereka pada akhirnya bertindak sebagai konsultan digital yang membentuk strategi, konten, dan eksekusi digital.

\section{Branding dalam Politik}

Branding adalah konsep yang awalnya digunakan dalam pemasaran, kemudian berkembang ke berbagai disiplin ilmu termasuk komunikasi dan politik. Pyke \& Ryan (2004) melihat sebuah brand berdasarkan tiga elemen (dalam Salamah \& Yananda, 2020), yaitu identitas, citra, dan positioning. Identitas adalah apa yang diproyeksikan brand melalui positioning untuk menciptakan citra tertentu. Penelitian-penelitian terdahulu juga banyak mengupas konsep personal branding, yaitu sebagai seperangkat karakteristik individu (atribut, nilai, kepercayaan, dll.) yang diterjemahkan ke dalam narasi yang berbeda dan citra dengan maksud untuk membangun keunggulan kompetitif dalam pikiran khalayak sasaran (Gorbatov S., et al, 2018).

Branding politik menyoroti fenomena yang berkembang bahwa partai, politisi, dan pemimpin politik dapat secara berguna dikonseptualisasikan sebagai merek. Branding dalam politik dimanfaatkan aktor politik untuk menciptakan awareness kepada publik secara umum atau pemilih. Branding politik didefinisikan konsep, teori, dan kerangka kerja politik untuk memberikan diferensiasi dari pesaing politik dan identifikasi antara warga negara dan entitas 
politik (Harris dan Lock, 2010; Needham \& Smith 2015). Konsep branding ini dirancang untuk pemimpin, partai dan kebijakan untuk membedakan dari persaingan. Branding ini akan membangun kepercayaan, yang kemudian mempengaruhi partisipasi politik.

Branding semakin banyak digunakan dalam politik untuk menggabungkan simbolisme, ideologi, nilai, dan janji kebijakan ke dalam partai/kandidat politik. Oleh karena itu, branding ini tidak hanya dimanfaatkan oleh aktor politik tetapi juga partai politik melalui serangkaian nilainilai, keyakinan, dan janji (Susila, I., Dean, et al., 2019). Penelitian terdahulu terkait pemilu di Indonesia juga menunjukkan bahwa pemilih berusia muda membangun pemahaman mereka tentang politik dan partai politik melalui "cerita" dan representasi simbolis calon politik" (Susila, Dean, \& Harness, 2015). Bagi Pich \& Dean (2015), politisi, pemimpin politik, dan partai sibuk membangun brand berdasarkan kemampuan, karakter, dan kepercayaan untuk memperoleh kepercayaan dan dukungan publik. Demokrasi membutuhkan kandidat dan partai yang dapat dipercaya.

Penelitian soal pentingnya branding pemimpin politik mulai menarik perhatian pada Pemilihan Presiden 2014. Joko Widodo dikenal sebagai sosok low profile dan nonmiliter. Kemudian pada Pemilihan Presiden 2019, Jokowi menampilkan dirinya sebagai pemimpin rakyat yang telah bekerja keras untuk pembangunan dan kemakmuran Indonesia (Susila, Dean, \& Harness, 2015). Studi lain menyoroti kaitan pengembangan strategi dan proses jangka panjang untuk mengembangkan dan mengelola brand (Pich, Armansdottir, dan Sigap 2018).

Selanjutnya, studi lain untuk menilai identitas, citra, reputasi, atau posisi yang pada akhirnya akan mendukung pengembangan strategi dan pengelolaan branding di politik (Nai \& Martinez, 2019). Bahwa ada the Big Five model yang menjelaskan ciri kepribadian manusia, extraversion (kemampuan bersosialisasi, energi, karisma), agreeableness (perilaku kooperatif, pro-sosial, penghindaran dan toleransi dan konflik), conscientiousness (disiplin, tanggung jawab dan perasaan bahwa hidup harus diatur), emotional stability (tenang, detasemen, tekanan emosional dan kecemasan rendah) and openness (rasa ingin tahu, kecenderungan untuk menciptakan pengalaman baru).

\section{METODE}

Artikel ini menggunakan pendekatan kualitatif melalui teknik literature review terkait branding yang dilakukan seorang pemimpin politik di media sosial. Literature review memiliki beberapa tujuan, yaitu menginformasikan kepada pembaca hasil-hasil penelitian lain yang berkaitan erat dengan penelitian yang dilakukan saat itu, menghubungkan penelitian dengan literatur-literatur yang ada, dan mengisi celah dalam penelitian-penelitian sebelumnya (Creswell, 2010). Literature review umumnya berisi ulasan, rangkuman, dan pemikiran penulis tentang beberapa sumber pustaka (artikel, buku, slide, informasi dari internet, data gambar dan grafik dan lain lain) tentang topik yang dibahas.

Artikel ini mengumpulkan berbagai studi terdahulu, yaitu memeriksa publikasi terbaru terkait branding yang dilakukan seorang pemimpin politik di media sosial. Metode yang digunakan pada tahap pencarian awal terkait topik terkait dari publikasi ilmiah yang ada. Pada tahap pengumpulan data menggunakan database perpustakaan dan google scholar untuk mencari artikel yang relevan dengan kata kunci yang sesuai.

Penelaahan artikel sebagai sumber literatur terpilih terkait topik branding oleh pemimpin politik di media sosia dan komunikasi politik. Terakhir penulis mencari literatur review perkembangan political branding di era digital. Kemudian dalam mengolah artikelartikel jurnal yang telah dikumpulkan, penulis menggunakan perspektif komunikasi politik 
dalam melakukan analisis, serta dihubungkan dengan konteks Indonesia dalam mengkorfirmasi fenomena tersebut.

\begin{tabular}{lll}
\hline No & Penulis/Judul & \multicolumn{1}{c}{ Gambaran Umum } \\
\hline 1 & Sianipar, Imelda (2015) & Artikel ini membahas Jokowi sebagai pemimpin \\
& populis Indonesia. Strategi yang digunakan Jokowi \\
& yaitu memiliki pengalaman organisasi, kepemimpinan \\
& dan prestasi, membangun koalisi, dan mengutamakan \\
& kebijakan yang berorientasi pada rakyat.
\end{tabular}

2 Roberta Bracciale \& Dalam sistem media hibrida, banyak proses yang Antonio Martella (2017) mereformasi komunikasi politik: popularisasi, disintermediasi, personalisasi, intimisasi, dan populisme. Penelitian ini menjelaskan tentang gaya komunikasi politik dengan tujuan untuk mengidentifikasi ciri-ciri gaya komunikasi politik kerakyatan. Antara 2015 dan 2016, garis waktu Twitter dari para pemimpin politik utama di Italia dianalisis selama 16 bulan.

Dengan menerapkan MCA, maka dapat mengidentifikasi dua faktor utama yang mencirikan gaya komunikasi pemimpin: (1) mode komunikasi, membandingkan negatif dan positif; dan (2) fokus komunikatif, membandingkan personalisasi dan kampanye politik.

Persinggungan antara mode komunikasi dan fokus komunikasi menghasilkan empat gaya komunikasi politik yang berbeda: 'Engaging', 'Intim', 'Champion of the people' dan 'Man of the street'. Dua yang terakhir ini jelas dicirikan oleh adanya fragmen dan sifat ideologi kerakyatan, tetapi tidak secara ketat terkait dengan posisi ideologis para pemimpin. Hasil ini mendukung hipotesis bahwa gaya populis semakin tidak terkait dengan belahan kanan/kiri politik, melainkan hasil dari kombinasi gradasi yang bervariasi yang mencampurkan aspek individu yang berbeda dari gaya komunikasi politik pemimpin.

3 Enli, G. (2017)

Dalam kampanye pemilihan presiden AS 2016, platform media sosial semakin banyak digunakan sebagai sumber berita langsung, melewati media editorial. Dengan jutaan pengikut kandidat, Twitter telah menjadi platform komunikasi massa dan saluran informasi online utama kandidat. Demikian juga, media sosial telah menyediakan platform untuk berdebat dan mengkritik media arus utama dengan kampanye dan 
Shannon C. McGregor, Studi ini berfokus pada 'personalisasi diri' politik Regina G. Lawrence \& kampanye, ditandai dengan kandidat yang menonjolkan Arielle Cardona (2017)

jaringan mereka. Artikel ini membahas strategi Twitter dari kandidat demokratis Hillary Clinton dan kandidat republik Donald Trump selama kampanye pemilihan presiden AS 2016. Sementara strategi kampanye Clinton menegaskan teori mengenai profesionalisasi kampanye pemilu, gaya kampanye Trump yang lebih amatir namun otentik di media sosial menunjukkan deprofesionalisasi dan bahkan amatirisme sebagai kontra-tren dalam komunikasi politik.

kehidupan pribadi mereka di atas posisi kebijakan mereka. Munculnya media sosial mungkin mempercepat pergeseran ini. Analisis konten terkomputerisasi skala besar dari posting media sosial oleh kandidat gubernur pada tahun 2014 menunjukkan bahwa kandidat laki-laki mungkin melihat lebih banyak dan kandidat perempuan melihat lebih sedikit manfaat strategis dalam personalisasi, tetapi efek ini tidak bertahan dalam menghadapi variabel kontekstual pemilihan seperti daya saing. Kami juga menemukan perbedaan kualitatif dalam cara calon laki-laki versus perempuan mempersonalisasikan melalui media sosial.

5 Manon Metz, Sanne Kruikemeier \& Sophie Lecheler (2020)

Dengan mengintegrasikan media sosial dalam komunikasi politik repertoar, politisi secara permanen berkampanye untuk mendapatkan dukungan online. Dengan mempromosikan agenda pribadi mereka, politisi semakin memprofilkan diri mereka atau melakukan personalisasi diri. Dengan berfokus pada personalisasi diri sebagai konsep berlapis-lapis (yaitu, profesional, emosional, personalisasi diri pribadi), penelitian ini menyelidiki penggunaan dan konsekuensi personalisasi diri pada

Facebook. Analisis konten manual dari Facebook ( $\mathrm{N}=$ 435) mengungkapkan bahwa personalisasi diri memang sering digunakan sebagai gaya komunikasi di Facebook dan paling sering hadir dalam komunikasi visual. Selain itu, penelitian menunjukkan bahwa penggunaan gaya yang lebih emosional dan pribadi memberikan alat yang bermanfaat untuk manajemen kesan politisi. Konten emosional dan pribadi menghasilkan efek positif pada keterlibatan, permintaan audiens untuk lebih intim dan kesan emosional.

Rizkika Lhena Darwin \& Artikel ini mengkaji pola personalisasi di tingkat lokal Haryanto (2021) di negara demokrasi terbesar di dunia Negara Muslim, 
Indonesia, di mana fenomena penting ini belum dieksplorasi. Temuan penelitian adalah karakteristik personalisasi di media sosial kampanye melalui penggunaan personalisasi Islam. Artikel ini menjelaskan motif dan kepribadian caleg perempuan yang menggunakan personalisasi Islami pada kampanye media sosial mereka di pemilihan kepala daerah di Indonesia. Untuk calon perempuan, Personalisasi Islami merupakan strategi kampanye untuk mendekatkan diri pemilih dan, pada saat yang sama, untuk menciptakan citra saleh bagi mereka. Semakin besar perkembangan personalisasi Islam, maka semakin tinggi tingkat tanggapan positif. personalisasi islami

dan media sosial meningkatkan jumlah media alternatif kampanye calon perempuan untuk bertarung dalam pemilu, dan bukan hanya untuk memenuhi persyaratan kuota. Studi ini menjelaskan tren personalisasi Islam yang meningkat secara signifikan di media sosial, yang telah mendukung tumbuhnya partisipasi politik bagi perempuan dalam kampanye pemilu, dan keterwakilan mereka di parlemen lokal.

$7 \quad$ Rahmah, S. (2021)

Media sosial sebagai sarana komunikasi politik digunakan untuk membangun kepercayaan masyarakat. Ganjar Pranowo merupakan salah satu aktor politik yang aktif menggunakan media sosial seperti Instagram untuk berkomunikasi dan berinteraksi yang sifatnya dua arah. Melalui media sosial, Ganjar Pranowo menjadi lebih dekat dengan masyarakat sehingga ia terpilih sebagai Gubernur Jawa Tengah selama dua periode.

\section{PEMBAHASAN}

Studi terkait penggunaan media sosial yang dimanfaatkan dalam komunikasi politik telah banyak menarik perhatian peneliti. Disebutkan bahwa para aktor politik, termasuk pemimpin politik ataupun calon pemimpin politik, menemukan strategi komunikasi politik yang efektif dan efisien untuk berkomunikasi dan berinteraksi dengan masyarakat melalui media sosial. Namun, tidak hanya sekadar menyampaikan informasi, pemimpin politik dengan sengaja membentuk branding sebagai bagian strategi komunikasi politik mereka untuk mendapatkan dukungan dan mempengaruhi masyarakat.

Untuk mendapatkan gambaran umum tentang aktivitas para pemimpin politik dalam melakukan komunikasi politik, penulis telah mengumpulkan tujuh literatur jurnal yang memenuhi kriteria. Brand pemimpin politik berimplikasi menjadi sosok pembeda dalam persaingan politik. Gaya komunikasi politik pemimpin politik di media sosial menjadi salah satu 
faktor penting untuk membentuk brand positif, melawan persepsi negatif, dan mempromosikan citra positif sosok pemimpin politik.

\section{Pemimpin populis}

Gaya kepemimpinan populis menjadi salah konsep penting dalam komunikasi politik. Populisme menjadi sentral, mengingat dalam beberapa tahun terakhir dukungan elektoral diperoleh oleh partai dan pemimpin yang bercirikan referensi populis (Albertazzi \& McDonnell, 2008; Kriesi, 2014;), bahkan populis menjadi gaya mainstream dalam demokrasi (Jagers \& Walgrave, 2007; Meny \& Surel, 2002), going public (Mancini, 2015; dalam Roberta Bracciale \& Antonio Martella, 2017). Populis dapat dianalisis dan dipahami, bahwa pemimpin politik didorong untuk berbicara dalam idiom yang lebih 'merakyat', popular, dan diterima oleh masyarakat agar mendapat dukungan.

Dalam hal ini, pemimpin politik mengkombinasikan penyampaian informasi dan hiburan untuk mempopulerkan dirinya dalam politik dan personalisasi yang melekat dalam logika media (Mazzo leni \& Sfardini, 2009). Roberta Bracciale \& Antonio Martella (2017) berpendapat, bahwa pemimpin politik mengadopsi gaya dan bahasa yang sesuai dengan kebutuhan pengikutnya di media sosial. Hasilnya adalah difusi jenis 'soft populism' dalam bingkai komunikasi langsung dan sederhana dengan perantara media sosial.

Studi Roberta Bracciale \& Antonio Martella (2017) terhadap tweet lima pemimpin politik di Italia, yaitu Matteo Salvini, Beppe Grillo, Giorgia Meloni, Matteo Renzi, dan Nichi Vendola pada 1 Januari 2015 s.d 1 Juli 2017 mengungkap bahwa di antara jenis media sosial, Twitter memainkan peran sentral dalam menghibridisasi dan mendefinisikan ulang komunikasi politik. Tweet telah menjadi versi digital dari soundbites, dan politisi menggunakannya untuk menjangkau audiens yang lebih luas berkat fitur yang tersedia. Disebutkan bahwa Twitter adalah media yang sempurna untuk pembentukan brand populis dalam mengimplementasikan komunikasi publik di era digital. Aktor politik (dalam hal ini pemimpin politik) menggunakan media sosial dengan tiga alasan utama,(1) untuk mengurangi kompleksitas ideologi dengan menyederhanakan pesan mereka; (2) mengaburkan ideologi kerakyatan untuk memfasilitasi masuknya pesan mereka dalam 'bingkai tindakan pribadi'; (3) untuk menyebarkan fragmen ideologi populis di antara orang-orang yang berpikiran sama.

Gaya komunikasi politik menjadi 'alat konseptual penting untuk menjelajahi ranah politik kontemporer'. Kunci dalam strategi komunikasi politik ini meliputi gaya, retorika, dan taktik yang digunakan aktor politik. Bracciale \& Antonio Martella (2017 meringkasnya ke dalam empat dimesi utama, yaitu (i) gaya; (ii) ideologi; (iii) retorika; dan (iv) strategi (Caiani \& Graziano, 2016). Namun, populis tidak perlu dipahami sebagai 'ideologi', karena hanyalah gaya kepemimpinan karena brand yang melekat ke diri pemimpin politik tersebut. Mengutip Pels (2003 dalam Roberta Bracciale \& Antonio Martella, 2017), gaya komunikasi populis adalah cara berbicara, bertindak, melihat, menampilkan, dan menangani yang bergabung menjadi keseluruhan simbolis yang memadukan materi dan cara, pesan dan paket, argumen dan ritual. Definisi ini menintegrasikan elemen verbal dan nonverbal untuk menyusun satu set unik komunikasi yang mencirikan komunikasi yang berbeda dari aktor politik yang beragam.

Dengan menggunakan multiple correspondence analysis (MCA) terungkap dua aspek spesifik yang membantu menentukan gaya komunikasi yang digunakan oleh para pemimpin: mode komunikasi (positif vs. negatif) dan fokus komunikatif tweet (pribadi vs. politik/kampanye). Dimensi pertama, khususnya penting dalam mengidentifikasi gaya komunikasi populis, diekspresikan dalam dua pertunjukan komunikatif yang berbeda: pertama 
'Champion of the people', gaya yang diarahkan untuk membela rakyat melawan elit, yang terutama mencakup masalah politik, pengambilan posisi, sederhana dan informal; dan kedua 'Man on the street', karakter yang ditampilkan dengan bahasa yang lebih vulgar yang mengeksploitasi kecemasan, ketakutan, berita, dan kebijakan lokal.

Berdasarkan fokus komunikatif tweet, yang pertama diberi label 'Intim', gaya yang ditujukan untuk mempersonalisasi narasi politik melalui berbagi emosi dan aspek kehidupan pribadi atau obrolan sederhana tentang urusan terkini; dan yang kedua diberi label 'Engaging', diarahkan untuk kampanye pemilu, promosi diri, dan keterlibatan penonton. Faktor ini merupakan bagian penting dari 'popularisasi' politik, yang didorong oleh logika media yang semakin banyak didorong oleh aktor politik dengan cerita, dan cerita pribadi dan intim. Indikator gaya populis dan personalisasi politik menghadirkan dua pendekatan komunikasi yang sangat berbeda di media sosial, di mana kehadiran ideologi populis dalam tweet merupakan ciri dari pendekatan populis dalam komunikasi politik digital.

Di Indonesia juga pernah memiliki pemimpin populis, yaitu Presiden Pertama Republik Indonesia Ir. Soekarno (Sianipar, Imelda, 2015). Brand populis melekat karena gaya kepemimpinannya yang kharismatik dan dekat dengan rakyat. Pada tahun 2014, Indonesia kembali memiliki pemimpin yang dicitrakan poplis yaitu Joko Widodo atau Jokowi. Sebagai sosok populis, brand Jokowi yang melekat adalah merakyat, berempati, dan kerja nyata.

Komunikasi politik yang dilakukan Jokowi melalui media sosial yaitu dengan tiga strategi. Pertama, Jokowi mengandalkan kerja. Kedua, gaya blusukannya memberikan harapan baru kepada masyarakat kecil. Ketiga, Jokowi mengepankan kehati-hatian dalam membuat kebijakan.

\section{Pemimpin Profesional Vs Amatir}

Studi yang dilakukan Gunn Enli (2017) membahas penggunaan media sosial dalam kampanye pemilu calon presiden AS tahun 2016 dengan kandidat Hillary Clinton dan Donald Trump. Fokus studi adalah interaksi kandidat dengan pemilih melalui media sosial secara professional atau amatir. Terdapat tiga temuan, yaitu: pertama, kampanye pemilu menggunakan media sosial digunakan sebagai alat pemasaran. Terkait keterlibatan dengan pengikutnya di media sosial, Donald Trump menerapkan strategi untuk membatasi membatasi keterlibatannya untuk me-retweet tweet yang dipilih. Untuk membentuk brand, politisi mengontrol pesan dan berpromosi untuk memulai kampanye debat publik yang terbuka.

Kedua, kampanye melalui media sosial terus berkembang dengan menampilkan komunikasi politik profesional ditantang yang bersifat amatir. Hal ini karena masing-masing kandidat memilih memanfaatkan infrastuktur teknologi untuk komunikasi jaringan. Hillary Clinton menampilkan tanda-tanda profesionalisasi yang jelas dalam kampanye sosial. Sementara Donald Trump cenderung lebih amatir. Namun, kampanye politik amatir ini memiliki klaim retoris untuk keaslian yang berhasil bersaing dengan profesionalisme kampanye yang lebih halus atau terkontrol. Dari budaya politik yang sangat berbeda dengan pemilihan presiden AS, Perdana Menteri Norwegia Solberg menggabungkan profesionalisme dan amatirisme di situs media sosialnya sehingga lebih mudah diakses daripada Clinton, tetapi lebih tenang daripada Trump.

Ketiga, temuan dalam penelitian bahwa media sosial adalah sarana untuk membangun dan mempertahankan citra kandidat. Media sosial merupakan peluang bagi pihak luar politik dan amatir untuk melakukan komunikasi politik agar berhasil. Hal ini diyakini peneliti mengganggu zona nyaman politisi mapan dan profesional. Gaya kampanye Trump yang lebih 
amatir namun otentik di media sosial menunjukkan deprofesionalisasi dan bahkan amatirisme sebagai kontratren dalam komunikasi politik.

\section{Humanis dan Popular}

Di Indonesia, kepala daerah-kepala daerah sudah banyak yang aktif menggunakan media sosial untuk meningkatkan komunikasi politik dengan warganya. Sebut saja, Gubernur Jawa Barat Ridwan Kamil dan Gubernur DKI Jakarta Anies Baswedan, Gubernur Jawa Tengah Ganjar Pranowo. Media sosial memudahkan kepala daerah untuk berkomunikasi dengan masyarakatnya sehingga menjangkau publik lebih luas.

Dalam penelitian Rahmah, S. (2021), Gubernur Jawa Tengah Ganjar Pranowo terbilang sukses. Ia memiliki pengikut, yaitu 3,5 juta di Instagram, 1,9 juta di Twitter dan 1,2 juta di Facebook. Bahkan, berkat popularitasnya di media sosial, nama Ganjar Pranowo meroket dalam survei bursa pencalonan presiden. Elaktabilitas Ganjar jauh mengungguli Puan Maharani sebagai Ketua DPP Partai Demokrasi Indonesia Perjuangan (PDIP). Ganjar sukses membangun personal brand sebagai sosok pemimpin baik, humanis, dekat dengan rakyat sehingga membangun kepercayaan masyarakat terhadap dirinya ia yaitu dengan menuliskan 'Tuanku ya Rakyat, Gubernur cuma Mandat'. Branding ini juga membedakan dari kandidat lainnya.

Media sosial juga dimanfaatkan Ganjar Pranowo menjabarkan hasil kinerjanya sebagai kepala daerah Jawa Tengah. Konten-konten digitalnya berisi isu-isu strategis di wilayahnya di mana ia menyerap aspirasi dari masyarakat sehingga bisa mencari solusi bersama. Melalui media sosial, Ganjar Pranowo digambarkan sebagai sosok pemimpin humanis dan merakyat. Usaha tersebut membawa kesuksesan dengan terpilihnya Ganjar Pranowo sebagai Gubernur Jawa Tengah selama dua periode. Bahkan, elektabilitasnya memungkinkan ia menuju panggung politik nasional.

\section{Personalisasi di Media Sosial}

Salah satu isu dalam pemilihan anggota legislatif atau kepala daerah adalah isu keterwakilan perempuan di dalam politik. Bahkan, isu gender dianggap strategi dalam komunikasi politik (McGregor, S. et al, 2017). Di Amerika Serikat, kandidat pemimpin politik perempuan memanfaatkan media sosial untuk memposting konten yang mengeksploitasi kekuatan stereotip feminin dengan berbagi tentang kehidupan pribadi mereka - khususnya, peran pengasuhan apa pun yang mereka mainkan. Kandidat pemimpin politik juga menampilkan personalisasi mereka di media sosial dengan menampilkan citra diri yang menarik. Temuan kualitatif dalam studi tersebut bahwa kandidat pemimpin politik di media sosial mempersonalisasi diri mereka sebagai pengasuh untuk anak mereka. Namun, hal ini juga bisa menganggap pengasuhan tidak sesuai dengan kepemimpinan politik yang kompeten. Di media sosial, kandidat pemimpin politik perempuan yang memang lebih banyak menggunakan strategi komunikasi politik seperti itu di media sosial.

Studi Manon Metz, Sanne Kruikemeier \& Sophie Lecheler (2020) juga mengungkapkan bahwa politisi cenderung melakukan personalisasi diri di media sosial. Hal ini digunakan untuk mendapatkan dukungan publik secara online. Dengan mempromosikan agenda pribadi mereka, politisi semakin memprofilkan diri mereka atau melakukan personalisasi diri melalui Facebook. Personalisasi diri memang sering digunakan sebagai gaya komunikasi politik di Facebook dan paling sering hadir dalam komunikasi visual. Penggunaan gaya yang lebih emosional dan pribadi memberikan alat yang bermanfaat untuk manajemen kesan politisi. Konten emosional 
dan pribadi menghasilkan efek positif pada keterlibatan, permintaan audiens untuk lebih dekat dan menggugah emosi.

Di Indonesia, strategi personalisasi ini juga dimanfaatkan dalam komunikasi politik di media sosial oleh kandidat calon legislatif perempuan. Sebagai negara yang penduduknya paling banyak adalah Muslim, kandidat pemimpin politik ini menggunakan elemen religius di media sosial. Bahwa terdapat tren peningkatan elemen religius di media sosial dalam kampanye politik. Perempuan memiliki kesempatan yang sama dengan laki-laki dalam memanfaatkan dan memaksimalkan strategi kampanye media sosial. Personalisasi perempuan Islami di konten digital media sosial berfungsi sebagai strategi kampanye yang efektif. Strategi ini secara positif efektif karena memberikan lebih banyak ruang bagi perempuan di Aceh untuk meningkatkan partisipasi politik. Semakin kuat figur sholeha caleg perempuan, semakin tinggi tingkat tanggapan positif yang diterima dari pemilih.

Seperti halnya dengan komunikasi secara umum, komunikasi politik juga bertujuan untuk menyampaikan pesan dari aktor politik kepada publik dengan tujuan tertentu. Setidaknya ada empat tujuan komunikasi menurut Effendy (2003), yaitu perubahan sikap (attitude change), perubahan pendapat (opinion change), perubahan perilaku (behavior change), dan perubahan sosial (social change). Dalam konteks politik, komunikasi politik oleh Denton dan Woodward didefiniskan sebagai komunikasi yang memiliki tujuan politis dengan ciri-ciri: komunikasi dilakukan oleh aktor politik dengan tujuan tertentu; komunikasi yang ditujukan kepada aktor politik oleh aktor nonpolitik; dan komunikasi terkait aktor politik melalui media massa tradisional (dalam McNair, 1995).

Seiring berkembangnya teknologi dan informasi, komunikasi politik memanfaatkan media sosial untuk mencapai tujuan yang ditetapkan. Bahkan, kehadiran media sosial telah terbukti mencapai kesuksesan menuju era demokrasi digital. Misalnya, adalah kemunculan gerakan sosial Arab Spring, Occupy Wall Street di New York, dan lainya.

Media sosial adalah salah satu medium baru yang berfungsi berkomunikasi sekaligus mempengaruhi opini publik. Mengutip praktisi media sosial Ismail Fahmi dalam Kompas.com (21/5/2021), saat ini marak kepala daerah yang menggunakan media sosial dalam berkomunikasi dan berinteraksi dengan warganya. Contohnya adalah Gubernur Jawa Barat Ridwan Kamil, Gubernur DKI Jakarta Anies Baswedan, Gubernur Jawa Tengah Ganjar Pranowo, dan lainnya.

Artikel ini menjelaskan beberapa temuan berdasarkan conceptual paper dari tujuh literatur yang dianalisis penulis. Secara umum, media sosial telah memfasilitasi pemimpin politik dan kandidat pemimpin politik untuk mencapai tujuan politiknya. Keberhasilan menggunakan media sosial dipandang sebagai salah satu faktor kesuksesan Barack Obama memenangi pemilihan presiden Amerika Serikat. Di Indonesia, Ridwan Kamil dan Ganjar Pranowo secara aktif menggunakan media sosial mendulang suara terbanyak sehingga didaulat menjadi Gubernur Jawa Barat dan Gubernur Jawa Tengah.

Media sosial sering dianggap sebagai platform yang memungkinkan hubungan lebih langsung antara pemimpin politik dan warganya. Media sosial berfungsi untuk mendukung kampanye para politisi (Verdegem P., D’heer E., 2018). Pada akhirnya, para pemimpin politik mulai menyadari pentingnya media sosial untuk melakukan komunikasi politik, ketimbang hanya memanfaatkan media massa arus utama.

Studi-studi tentang komunikasi politik di media sosial menjelaskan, bahwa media sosial dimanfaatkan untuk berkomunikasi dan berinteraksi dengan warganya (media untuk menghubungkan kembali dan terlibat dengan warganya. Hal ini menjadi tantangan dan peluang dengan menghadirkan struktur politik baru baru bagi politisi, jurnalis, institusi politik, dan 
media untuk menghubungkan kembali dan terlibat dengan warganya (Schwanholz J. \& Graham T, 2018). Selain itu, media sosial juga untuk menyerap aspirasi, dan membentuk branding sebagai sosok pemimpin yang layak (Hultman, M., 2019).

Terkait branding politik, hal ini merupakan fenomena yang telah berkembang bahwa partai, politisi, dan pemimpin politik dapat secara berguna dikonseptualisasikan sebagai brand atau merek. Branding dalam politik dimanfaatkan aktor politik untuk secara umum atau pemilih. Konsep branding ini dirancang untuk pemimpin, partai dan kebijakan untuk membedakan dari persaingan. Branding ini akan membangun kepercayaan, yang kemudian mempengaruhi partisipasi politik.

Studi terhadap literatur-literatur yang menjadi objek analisis memperluas manfaat bahwa media sosial digunakan oleh para aktor politik untuk mencapai tujuan politik. Politisi Italia Roberta Bracciale \& Antonio Martella (2017) dan Joko Widodo menciptakan brand yang populis melalui postingan di akun media sosialnya Sianipar, Imelda (2015). Demikian pula Ganjar Pranowo yang elektabilitasnya terdongkrak berkat popularitasnya di media sosial Rahmah, S. (2021). Namun perlu dilakukan studi lebih lanjut apakah pengelolaan brand dan popularitas pemimpin politik di media sosial memang selalu berkorelasi dengan pencapaian politik. Dalam studi yang dilakukan Enli, G. (2017) menjadi temuan menarik bahwa gaya kampanye Donald Trump yang lebih di akun media sosialnya, serta deprofesionalisasi dan bahkan amatirisme lebih disukai pemilih karena otentik. Komunikasi politik ini juga untuk membedakan dari aktor politik yang beragam sehingga dapat memunculkan brand tertentu.

\section{KESIMPULAN}

Fenomena komunikasi politik di era media sosial menjadi praktik yang biasa dilakukan dalam politik saat ini. Semula praktik komunikasi politik tersebut menggunakan saluran 'tradisional', tetapi seiring berkembangnya teknologi beralih secara digital. Penulis juga menemukan bahwa faktor penting bagi seorang pemimpin politik untuk dapat meraih popularitas di media sosial haruslah memiliki brand yang baik sehingga tujuan komunikasi politik dapat tercapai dengan efektif. Yaitu dalam memperoleh dukungan dan mempengaruhi pengikut media sosial mereka.

Brand, image, ataupun kredibilitas telah terbukti berperan dalam menjelaskan efek dukungan terhadap pemimpin politik di media sosial. Selain itu, pemimpin politik di media sosial juga harus memiliki engagement dengan pengikutnya. Karena karakter dari media sosial adalah bersifat interaktif dan dua arah. Hal ini bermanfaat untuk menyerap aspirasi dari masyarakat.

Artikel ini diharapkan dapat mengisi kekurangan kajian sebelumnya yang telah ada terkait branding dalam politik di era komunikasi politik digital dengan memanfaatkan media sosial, tetapi juga mampu memberikan kontribusi pengetahuan bagi pemimpin politik, praktisi dan konsultan politik, media social specialist dalam mengenali konsep branding dalam politik. 


\section{DAFTAR PUSTAKA}

Cropanzano, R. (2009). Writing nonempirical articles for Journal of Management: General thoughts and suggestions. Journal of Management, 35, 1304-1311.

Daniel Kreiss \& Shannon C. McGregor. (2018) Technology Firms Shape Political Communication: The Work of Microsoft, Facebook, Twitter, and Google With Campaigns During the 2016 U.S. Presidential Cycle, Political Communication, 35:2, 155-177, DOI: 10.1080/10584609.2017.1364814

Dijk, Jan Van. (2006). The Network Society. London: Sage Publications.

Enli, G. (2017). Twitter as arena for the authentic outsider: exploring the social media campaigns of Trump and Clinton in the 2016 US presidential election. European Journal of Communication, 32(1), 50-61. https://doi.org/10.1177/0267323116682802

Hafizatullah, Salamah \& Wangi. (2017). The usage of social media as a form of external public communication (Case study on Ridwan Kamil as the mayor of Bandung). Proceeding of The 4th Conference on Communication, Culture and Media Studies

Harris, L. and Rae, A. (2011), "Building a personal brand through social networking", Journal of Business Strategy, Vol. 32 No. 5, pp. 14-21. https://doi.org/10.1108/02756661111165435

Gilson LL, Goldberg CB. Editors' Comment: So, What Is a Conceptual Paper? Group \& Organization Management. 2015;40(2):127-130. doi:10.1177/1059601115576425

Gorbatov, Sergey \& Khapova, Svetlana \& Lysova, Evgenia. (2018). Personal Branding: Interdisciplinary Systematic Review and Research Agenda. Frontiers in Psychology. 9. 1-17. 10.3389/fpsyg.2018.02238.

Kemp S., Digital 2021: Indonesia, 2021, https://datareportal.com/reports/digital-2021-indonesia

Khamis, Sahar. (2013). "Cyberactivism" in the Arab Spring: What Social MediaCan and Can Not Do. International Affairs Forum. Vol 4, Issue 1,

Manon Metz, Sanne Kruikemeier \& Sophie Lecheler (2020) Personalization of politics on Facebook: examining the content and effects of professional, emotional and private selfpersonalization, Information, Communication \& Society, 23:10, 1481-1498, DOI: 10.1080/1369118X.2019.1581244

Margaret Scammell (2015) Politics and Image: The Conceptual Value of Branding, Journal of Political Marketing, 14:1-2, 7-18, DOI: 10.1080/15377857.2014.990829

McNair, Brian. An Introduction to Political Communication. London \& New York: Routledge, 1995. 
Perloff, R. M. (2021). The Dynamics of Political Communication: Media and Politics in a Digital Age. Amerika Serikat: Routledge

Pich, C., G. Armannsdottir, and L. Spry. 2018. "Investigating Political Brand Reputation with Qualitative Projective Techniques from the Perspective of Young Adults." International Journal of Market Research 60 (2):198. doi: 10.1177/1470785317750817.

Pich, C., and D. Dean. 2015. "Political Branding: Sense of Identity or Identity Crisis? An Investigation of the Transfer Potential of the Brand Identity Prism to the UK Conservative Party." Journal of Marketing Management 31 (11-12): 1353-1378. doi: 10.1080/0267257X.2015.1018307.

Nai, A., and F. Martinez. 2019. "The Personality of Populists: Provocateurs, Charismatic Leaders, or Drunken Dinner Guests?" West European Politics 42 (7):1337. doi: 10.1080/01402382.2019.1599570.

Needham, C., and G. Smith. 2015. "Introduction: Political Branding." Journal of Political Marketing 14 (1-2):1. doi: 10.1080/15377857.2014.990828

Norris, P. (2001). Theories of Digital Democracy. In Digital Divide: Civic Engagement, Information Poverty, and the Internet Worldwide (Communication, Society and Politics, pp. 95-111). Cambridge: Cambridge University Press. doi:10.1017/CBO9781139164887.008

Rizkika Lhena Darwin \& Haryanto (2021) Women candidates and Islamic personalization in social media campaigns for local parliament elections in Indonesia, South East Asia Research, 29:1, 72-91, DOI: 10.1080/0967828X.2021.1878928

Roberta Bracciale \& Antonio Martella (2017) Define the populist political communication style: the case of Italian political leaders on Twitter, Information, Communication \& Society, 20:9, 1310-1329, DOI: 10.1080/1369118X.2017.1328522

Salamah, U \& Yananda, R. (2020). The Many Faces of Wonderful Indonesia: Tourism Brand in Sixteen Countries Online News Sites. Jurnal Komunikasi Indonesia Volume IX, No 1, March 2020.

https://doi/org/10.7454/jki.v9i1.11586

Schwanholz J., Graham T. (2018) Digital Transformation: New Opportunities and Challenges for Democracy?. In: Schwanholz J., Graham T., Stoll PT. (eds) Managing Democracy in the Digital Age. Springer, Cham. https://doi.org/10.1007/978-3-319-61708-4_1

Shannon C. McGregor, Regina G. Lawrence \& Arielle Cardona (2017) Personalization, gender, and social media: gubernatorial candidates' social media strategies, Information, Communication \& Society, 20:2, 264-283, DOI: 10.1080/1369118X.2016.1167228 
Susila, I., Dean, D., Yusof, R. N. R., Setyawan, A. A., \& Wajdi, F. (2019). Symbolic Political Communication, and Trust: A Young Voters' Perspective of the Indonesian Presidential Election. Journal of Political Marketing, 1-23. doi:10.1080/15377857.2019.1652224

Vedel, Thierry. Political Communication in New Era: Political Communication in The Edge of Internet (Chapter 3). London \& New York: Routledge, 2003.

Verdegem P., D'heer E. (2018) Social Media Logic and Its Impact on Political Communication During Election Times. In: Schwanholz J., Graham T., Stoll PT. (eds) Managing Democracy in the Digital Age. Springer, Cham. https://doi.org/10.1007/978-3-319-6170 